\title{
LEGISLATIVE CONTROL OF CONSUMER CREDIT TRANSACTIONS
}

\author{
Paul R. Moo*
}

Legislative controls in the area of consumer credit transactions are of comparatively recent origin. Consumer credit, as we understand it today, did not begin to develop until the late nineteenth century. Up until the period of the First World War, credit facilities available to consumers generally were largely confined to credit on open account extended by the local merchant in the local community to his established clientele and to cash loans by pawnbrokers, wage brokers, and loan sharks in the urban areas. Mass production and marketing of the automobile had not yet begun, and installment selling, which we take for granted today, had not become a significant economic factor. At the end of the First World War there was outstanding less than one billion dollars of consumer installment credit, excluding real estate mortgages. ${ }^{1}$ Recent available statistics indicate that consumer credit outstandings have soared to over one hundred billion dollars. ${ }^{2}$

This explosion in the use of credit by consumers, if no other reason, explains the current interest and concern over the state of the law governing consumer credit transactions. The hearings, discussions, and controversy leading to the adoption by Congress of the Consumer Credit Protection Act of Ig68 (the CCPA), ${ }^{3}$ and the development and promulgation by the National Conference of Commissioners on Uniform State Laws of a uniform code governing consumer credit transactions (the UCCC), ${ }^{4}$ have attracted, for the first time, the widespread attention of the practicing bar and the teaching branch of the legal profession to the problems inherent in the extension of credit to the consumer. The legal literature and court precedents available in the consumer credit area are meager indeed.

The purpose of this article will be to give the reader a brief look at the history and background of consumer credit regulation and then an overview of the CCPA and the UCCC.

\section{History and Background}

Prior to the First World War, with the exception of legislation in a few states regulating pawnbrokers, the only legal control over consumer credit transactions

\footnotetext{
* B.S. x942, J.D. 1947, Indiana University. Member of firm of Voor, Jackson \& McMichacl, South Bend, Ind. Member of the Indiana bar.

1 Board of Governors, Federat Reserve Systeas, Consumer Instalment Credit 25 (1957).

254 Fed. Res. Butl., No. ro, at A-52 (1968).

${ }^{3} 82$ Stat. $I_{4} 6$ (I968) [hereinafter cited as CCPA].

4Uniform Consunier Credir Code (hereinafter cited as UCCC). On the text of the UCCC, see Foreword, in this symposium, p. 639 n.r.
} 
was that found in the general interest and usury statutes which historically were designed and developed to control and regulate business transactions. Devices to circumvent the existing interest and usury laws were obviously required in order to extend cash credit to the consumer in small amounts and for short periods of time. One of the most popular was the wage broker or salary buyer plan in which the "lender" would agree to "purchase" the consumer's salary at a substantial present discount of its future value. In about Igro, Arthur J. Morris, a lawyer, devised a plan for making installment cash loans to consumers within the limitations of the general interest and usury statutes. The so-called Morris Plan involved the making of a single payment loan to the consumer at the legal rate of interest coupled with a requirement for the consumer to purchase from the lender on a monthly payment basis investment certificates. "Upon maturity of the loan the "deposits" in the customer's investment certificate account would simply be applied to the payment of the consumer's debt. The economic effect of the Morris Plan operation was to permit the lender approximately to double the yield on the loan he made to the consumer. ${ }^{6}$ Most consumer cash credit, however, was simply extended by loan sharks who were oblivious to the legal controls and willing to take the risks of the interest and usury law penalties.?

In Igr6, under the auspices of the Russell Sage Foundation, a Uniform Small Loan $\mathrm{Act}^{8}$ was drafted to legitimatize and regulate the extension of cash loan credit to the consumer. Between the world wars a significant number of states adopted the Uniform Small Loan Act for the dual purposes of making cash loans available to the consumer and stamping out the loan shark evil. During this period a number of states also authorized, by legislation, operations of so-called Morris Plan or industrial banks.

In the period between the wars, vendor credit remained largely an accommodation by the local merchant to his valued customers and was extended without a charge therefor and customarily on the basis of thirty-day terms. The exception to this pattern originated with the sale and financing of automobiles. Shortly after the First World War, and during the interwar period, there were a number of automobile sales finance companies organized. Their growth was as phenomenal as the growth in sales of Henry Ford's Model T. The activities of these sales finance companies, however, as their name implied, was confined almost exclusively to

\footnotetext{
- This plan of lending was used in Texas, a state with a constitutional interest limitation, until I96r when the courts of that state finally recognized that the lending and deposit transactions were actually a single, unitary consumer lending device. Community Fin. \& Thrift Corp. v. State, I6r Tex. 6I9, 343 S.W.2d 232 (I96I); accord, O'Brien v. Atlas Fin. Co., 223 Ark. I76, 264 S.W.2d 839 (I954).

${ }^{-}$A single payment loan of $\$ 100$ for one year at $7 \%$ interest produces a yield of $\$ 7$. If the borrower repays the loan in monthly installments, the lender still receives $\$ 7$ but has had an average of only $\$ 50$ outstanding over the period of the year, thus, in effect, approximately doubling his yield.

${ }^{7}$ See Benfield, Money, Mortgages and Migraine-The Usury Headache, r9 CaSE W. Res. L. Rev 8rg, $838-840$ (rg68).

${ }^{8}$ The seventh and latest draft (1942) of the uniform small loan law is reprinted in B. CURRAN, Trends in Consunger Credit Legislation i44-57 (I965).
} 
financing the distribution and sale of automobiles. In the early I930s credit unions were first organized in significant numbers, and in large measure they were an outgrowth of the great depression. The major growth and expansion of credit unions dates from the passage of the Federal Credit Union Act in $1934 .^{\circ}$

Historically, commercial banks were reluctant to participate in the consumer credit market. With the exception of making mortgage loans on residential real estate, banks during the rgzos engaged in very little direct lending to consumers or even in the sales finance business. It was not until the I930s, when sources for business loans were limited and after the sales finance and consumer finance companies had demonstrated the credit capacity and reliability of the consumer, even in the depths of the great depression, that commercial banks became interested in loans to consumers on an installment basis and in acquiring consumer goods paper.

Legislative activity in the I920s and I930s was largely confined to the consideration, passing, and amending of small loan and Morris Plan or industrial bank statutes. Just before the outbreak of the Second World War retail installment sales acts were adopted in Indiana, Wisconsin, and Maryland, but at the war's outbreak these were the only states which regulated or controlled by legislation the purchase or financing of goods or services on an installment plan.

Special legislation authorizing and permitting certain creditors to extend cash loans at rates of charge above the basic interest rates was required because of the existence of general interest and usury statutes. On the other hand, vendor credit or sales credit required no authorizing legislation. The legal basis for sales credit and for the activities of sales finance companies was and is the time-price doctrine. That legal doctrine, as old as the English common law itself, was and is an embodiment of the legal principle that the owner of any piece of property, real or personal, has the right and privilege to sell his property to any other person for such price as the vendor may choose. ${ }^{10}$ If the owner chooses to sell at one price for cash in hand today but at a different and larger price to be paid at some future date, in installments or otherwise, that too is his legal right. The difference between the cash price and the installment or time sales price was not construed or considered to be a charge for the use of money (interest), since no loan of money was involved; nor was such difference treated as a forbearance (delay in the enforcement of an existing contract right) as there was not an agreement to sell at a cash price and then a second or subsequent agreement to postpone or defer the time of payment thereof. ${ }^{11}$ Since the time-price doctrine was firmly imbedded in the common law of practically every state, no legislative action was required to permit the expansion of consumer sales credit. On the contrary, when Indiana, Wisconsin, and Maryland adopted

\footnotetext{
${ }^{9}$ I2 U.S.C. $\$ \$ \mathrm{I}_{75} \mathrm{I}-72$ ( 1964$)$.

${ }^{10}$ See, e.g., Hogg v. Ruffner, 66 U.S. (I Black) x15, II8-rg (186r).

11 B. Curran, supra note 8, ch. 4, contains a general discussion of the time-price doctrine. See Annot. I43 A.L.R. 238 (1943); Annot., I4 A.L.R.3rd 1065 (1967); Warren, Regulation of Finance Charges in Retail Installment Sales, 68 YALE L.J. 839 (1959).
} 
retail installment sales acts, they were in form and in fact controlling or regulating an existing legal right or privilege.

During the period following the Second World War we have seen almost a literal explosion not only in the use but in the kinds of consumer credit. Installment credit is available to the consumer today from commercial banks, sales finance companies, credit unions, small loan companies, industrial banks, consumer finance companies, other financial institutions, department stores, furniture stores, appliance stores, automobile dealers, oil companies, and other retail outlets. Accompanying this explosion in the use of consumer credit we have seen a gradual but dramatic increase in the maximum size of loans which may be made under small loan laws. We have witnessed the development of more and more large loan laws and the passage by state after state of special lending laws for commercial banks. We have observed the "commercialization" of credit unions and an expansion of their powers and services. In the area of vendor credit we have observed the automobile sales finance companies changing the character of their business so as to make sales finance credit available to sellers of appliances, furniture, mobile homes, farm equipment, trucks, trailers, and virtually all other types of large-ticket hard goods. More recently, we have seen a broadening of the powers of state and federal savings and loan associations in the consumer credit area and are witnessing considerable agitation for their further expansion into the consumer credit area. Even more recently, commercial banks, oil companies, and others have begun issuing multipurpose credit cards, check-credit plans have been instituted by commercial banks, and other creditors are expanding the availability of consumer credit-frequently without the benefit of enabling legislation and in apparent disregard of the existing general interest and usury statutes.

Since the Second World War, the large independent and chain department stores, mail order houses, and even variety stores have moved from their traditional cash-and-carry philosophy to aggressive promotion of installment credit selling. These retailers have asserted that their sales on a deferred (usually revolving) payment plan were entitled to the protection of the time-price doctrine-this even though at the time and point of sale there is no agreement for a fixed time price, but rather a cash purchase price for the merchandise and a later elective deferment of the date of payment therefor. ${ }^{12}$ Beginning in about 1955, revolving sales credit acts were adopted in state after state, and today we find such laws in existence either as separate acts or as a part of a sales finance statute in a majority of the states. ${ }^{13}$

During the I940s and the early part of the I950s, from time to time a court would find a particular consumer credit sale transaction to have been a loan. In the absence of consumer credit regulatory laws, however, a court seeking to establish

\footnotetext{
${ }^{23}$ Litigation seriously challenging the application of the time-price doctrine to retail revolving credit sales is presently pending in both Wisconsin and Colorado. See also I4 A.L.R.3d 1065, II28 (I967).

${ }^{19}$ See I CCH InSTallament CRedit Gume \$35.
} 
a fair balance between protecting consumers against excessive finance charges, harsh practices, or other abuses in a credit sale of goods or services and at the same time maintaining the vitality and validity of the time-price doctrine was frequently faced with a hard choice. If the court was inclined to protect the consumer, it would do so by finding the sales transaction to be either a loan or a forbearance, thus forcing installment credit sellers to comply with outmoded interest and usury statutes. If the court chose the other alternative and perpetuated the time-price doctrine, it necessarily denied the consumer all legal protection against excessive charges or other abuses. By and large the courts followed common law precedent in continuing to find retail installment sales transactions to be exempt from the control of general interest and usury statutes. ${ }^{14}$

In 1952, however, the Supreme Court of Arkansas decided that the time-price doctrine would no longer be followed in that state when the seller of merchandise immediately discounted or sold the installment contract to a financial institution. ${ }^{15}$ Obviously, this decision shocked the sales finance industry and the sellers of goods on credit. In I955, a federal court of appeals concluded that a particular sales transaction was not within the time-price doctrine, ${ }^{16}$ and at about that same time the Supreme Court of Nebraska came to the same conclusion. ${ }^{17}$. The fact pattern in these cases was not unusual or uncommon. Also in 1955 the Attorney General of Nebraska levied a broad scale attack against the very foundations of the sales finance business, ${ }^{18}$ and this was soon followed by similar action by the Attorney General in Kansas. ${ }^{19}$ The legislatures of the various states were now called to action in the sales credit field. In the five-year interval from 1956 to $\mathrm{Ig} 6 \mathrm{r}$, some twenty-six states which had never before had such acts passed legislation controlling and regulating consumer sales credit transactions. Substantial changes were made in the laws of an additional twelve states.

In recent legislative years there have been added to the motor vehicle control acts and all goods control acts, ${ }^{20}$ special statutes regulating particular kinds of consumer credit transactions. Specifically, statutes have been adopted regulating home improvement financing, ${ }^{21}$ insurance premium financing, ${ }^{22}$ and even health and dance studio contracts. ${ }^{23}$ Even more recently, several states have passed second mortgage finance control acts. ${ }^{24}$

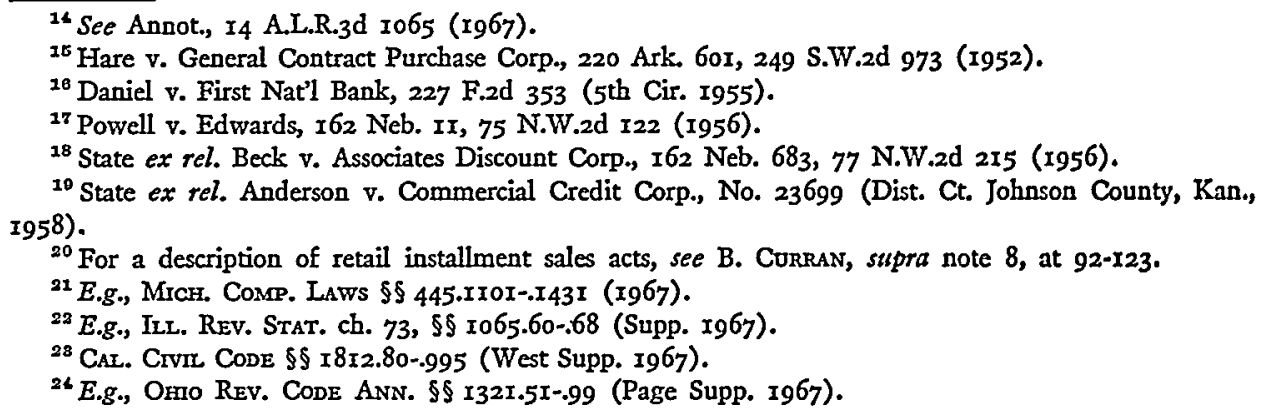


Since about 1960 we have also seen an increasing emphasis on consumer protection laws. The highly controversial Douglas bill, which the Senator called a law to provide "truth in lending," is familiar to most everyone. In the early part of the Kennedy administration there was appointed a Consumer Advisory Council to the President of the United States. President Johnson appointed a consumer advisor and reorganized the President's Council on Consumer Credit. A proposal to create a cabinet-level office of a Secretary for Consumer Affairs has been recurrently offered in the past few years. Studies of consumer credit laws have been authorized in recent years by various state legislatures, and some states have adopted consumer fraud laws under which the state attorney general is authorized and directed to investigate all sorts of allegations of consumer fraud. ${ }^{25}$

To those not familiar with the history and development of consumer credit regulatory statutes, the existing legal structure appears to be a hodge-podge of legislative action. The first integrated study of the whole body of laws applying to consumer credit arrangements was commissioned by the American Bar Foundation and published as recently as $1965 .{ }^{26}$ While this study focused primarily on the then existing state laws regulating and controlling consumer credit loan and sales transactions, it also examined legislation covering related matters such as credit insurance laws, debt pooling statutes, and laws governing assignment and garnishment of wages and wage earner plans under the Bankruptcy Act. This study amply demonstrates the sheer mass ${ }^{2 \tau}$ and complexity ${ }^{28}$ of the consumer credit regulatory statutes which presently exist and pointed up the fact that only the highly specialized lawyer serving consumers or creditors could know or find the relevant statutory materials in dealing with a consumer credit problem. ${ }^{29}$

THE CCPA

The Consumer Credit Protection Act (CCPA) passed by Congress in 1968 has done nothing to simplify or systematize the existing body of credit control legislation. With the exception of the provisions intended to reduce the income to organized crime from "extortionate credit transactions" (loan sharking), ${ }^{30}$ the restrictions on wage garnishments to become effective July $\mathbf{I}, \mathbf{1 9 7 0 ,}{ }^{31}$ and the right created to rescind certain real estate credit transactions, ${ }^{32}$ the CCPA merely adds to the

\footnotetext{
${ }^{25}$ E.g., ILI. REv. STAT. ch. 12I $1 / 2, \$ \$ 26 \mathrm{I}-272$ (Supp. 1967 ).

${ }^{\text {so }}$ B. Curran, supra note 8.

${ }^{87} I d$., charts $I$ and $I I$.

${ }^{28}$ Id., charts I-27.

${ }^{20}$ One of the basic assumptions for development of the UCCC was that "consumer credit legislation should be contained in one law so that any attorney can quickly and effectively advise his consumer client." UCCC, Prefatory Note.

${ }^{30}$ CCPA, tit. 2, especially $\S 201$ (a)(I). See Malcolm \& Curtin, The New Federal Attack on the Loan Shark Problem, in this symposium, p. 765 .

${ }^{2 x}$ CCPA, tit. 3 .

${ }^{22} \mathrm{CCPA} \$ 125$.
} 
existing confusion by requiring all creditors to disclose the charges being made for an extension of credit in terms of annual percentage rate ${ }^{33}$ Basically the CCPA is only a disclosure law. It does not regulate or control finance charges, contract provisions or limitations, debtors' remedies, or any of the substantive features of a consumer credit transaction. In fact, Congress has stated that the adoption of federal disclosure requirements does not annul, alter, affect, or excuse a creditor from complying with, the existing provisions of any state regulatory statute. ${ }^{34}$ In my opinion, the superimposing of federal disclosure requirements on the existing legal structure for consumer credit has and will create more problems than it will solve.

The UCCC, which was developed during the same period that the "Douglas bill" (which was the forerunner of the CCPA) was pending in the Congress, has been modified to conform with the federal disclosure requirements, but, unlike the CCPA, the UCCC makes an effort to overhaul, modernize, and restructure all of the existing consumer credit regulatory statutes and to harmonize the disclosure requirements with all other regulatory features. Incidentally, while the UCCC was necessarily revised in its final draft to conform to the disclosure requirements of the CCPA, it can likewise be demonstrated without dispute that the earlier drafts of the UCCC substantially affected the final result of the federal statute.

Basically the CCPA requires creditors to disclose, clearly and conspicuously, and in accordance with regulations of the Federal Reserve Board, to each person to whom consumer credit is extended certain credit cost information and to comply with certain advertising restrictions and limitations. The disclosure requirements and advertising limitations of the federal law and of the UCCC are examined and discussed in another article in this symposium. ${ }^{35}$

One of the principal reasons that the final draft of the UCCC was modified and revised to conform with the disclosure provisions of the CCPA was that Congress provided an express exemption from federal regulation and control of credit transactions within any state if the Board of Governors of the Federal Reserve System determines that such class of credit transactions is subject to disclosure requirements substantially similar to those imposed by the CCPA. ${ }^{36}$ It is anticipated that the Board of Governors will rule that the UCCC provides such "substantially similar" requirements.

\section{III}

\section{THE UCCC}

The UCCC is designed to supplant the existing hodgepodge of state statutes

\footnotetext{
${ }^{33} \mathrm{CCPA} \S \S 102,121,107$.

${ }^{34}$ CCPA $\S \mathrm{IIr}$.

${ }^{35}$ See Johnson, The New Law of Finance Charges: Disclosture, Freedom of Entry, and Rate Ceilings, in this symposium, p. $67 x$.

${ }^{36} \mathrm{CCPA} \S \mathrm{I23}$. The Board's determination standard is "requirements substantially similar" to the CCPA and "adequate" provision for state law enforcement.
} 
which presently control the extension and collection of all kinds of consumer credit. ${ }^{37}$ The UCCC provides for the repeal of all existing general interest and usury statutes; small loan acts; large loan acts; industrial loan statutes; commercial bank loan laws; retail installment sales laws; revolving credit, truth-in-lending, home solicitation, second mortgage, home improvement finance, insurance premium finance, and other special acts, ${ }^{38}$ as well as the elimination of the provisions of any other laws imposing maximum rates of charge or otherwise controlling consumer credit transactions. ${ }^{39}$ All consumer credit regulations would be combined into a single law, with separate articles, in a structure much like that of the Uniform Commercial Code. The UCCC consists of nine articles, two of which have been reserved for future use: I. General Provisions and Definitions; 2. Credit Sales; 3. Loans; 4. Insurance; 5. Remedies and Penalties; 6. Administration; 7. Reserved for future use for provisions concerning consumer credit counseling agencies; 8 . Reserved for future use for provisions concerning state wage earner receiverships; 9. Effective Date and Repealer.

\section{A. General Approach and Premises}

The UCCC does not displace or affect the limitations on the powers an organization, such as a savings and loan association or credit union, may exercise, nor is it intended to displace or affect the limitations on powers of commercial banks or other deposit-accepting institutions with respect to the amount of a loan to a single borrower, the ratio of a loan to the value of collateral, the duration of a loan secured by real estate, or other similar restrictions designed to protect deposits of the general public. ${ }^{40}$

Historically, regulation in the consumer loan field developed through, and has continued to be oriented to, separate laws for the different kinds of creditors such as small loan companies, industrial banks, commercial banks, or credit unions. Similarly, regulation in the consumer sales field has been fragmented into regulating credit sales of varying kinds of goods and frequently having different laws and rules for sales of goods on revolving payment plans as contrasted with installment payment plans. Departing from these traditional approaches, the UCCC regulates transactions rather than creditors or persons and does not differentiate between the sales of various kinds of consumer goods or services. The distinctions which exist today in consumer credit regulatory statutes between sales of automobiles on one hand and sales of other goods on the other, or between installment sales of goods and sales on revolving credit plans, are eliminated by the UCCC. Similarly, present restrictions on the size, maturity, or kinds of loans which may be made by small

\footnotetext{
${ }^{37}$ UCCC $\$ 1.102(2)$. Unless otherwise noted all subsequent footnote references are to articles, parts, or sections of the UCCC.

s8 9 9.103 $(1)$.

30 9.103(2).

$10 \$$ I.108.
} 
loan companies, by industrial banks, by credit unions, by commercial banks, or by other lenders are also eliminated.

A basic underlying assumption and policy embodied in the UCCC is that the supplying of consumer credit needs in society today can best be provided by a system of freely competitive institutions. Just as the consumer is best served by free and open competition among grocery stores, department stores, jewelers, clothing stores, gasoline stations, shoe repair shops, barbers, doctors, dentists, lawyers, and all of the other establishments in our society that provide goods and services to satisfy the consumer's wants and needs, so too the UCCC proceeds on the policy assumption that the marketplace should determine by whom and how the consumer's needs are supplied. ${ }^{41}$ The premise of the UCCC is that the best protection for the consumer and the best interests of those engaged in supplying consumer credit are served not by arbitrary legislative rules, not by regulations issued by some supervisory agency, but by competition in the market place.

The UCCC continues the distinction between consumer sales credit transactions and consumer loan transactions. ${ }^{42}$ One of the avowed purposes for the continuation of this separation of credit sales and consumer loans was to preserve the time-price doctrine in those states which had not yet adopted the UCCC. ${ }^{43}$ However, the need and desirability of having separate articles for sales and loans is also demonstrated by the differences in the respective disclosure provisions ${ }^{44}$ and contract limitation provisions, ${ }^{45}$ the need in the sales article for provisions on home solicitation sales, ${ }^{40}$ and the need in the loan article for special provisions as to higher rate lenders. ${ }^{47}$

One of the drafting and policy problems in the development of the UCCC was the manner of regulating credit cards, which have recently become very popular in the consumer credit area. The final decision was to treat the single-merchant credit card as being under the regulatory provisions of the sales article $e^{48}$ but to treat transactions under the multiple-purpose credit card as being within the regulatory provisions of the loan article. ${ }^{49}$ Since the issuer of a multiple-purpose credit card is directly financing the consumer rather than the seller of goods or services, the approach of the UCCC in treating the multiple-purpose credit card in the same category as a consumer loan appears theoretically sound.

\section{B. Coverage}

One of the principal tasks facing the draftsmen of the UCCC was to determine the

\footnotetext{
${ }^{\$ 1} \S 2.201$, Comment; $\$ 3.503$, Comment. See Johnson, The New Law of Finance Charges: Disclosure, Freedom of Entry, and Rate Ceilings, in this symposium, p. 671.

${ }^{2}$ Art. 2, Credit Sales; art. 3, Loans.

${ }^{43}$ Prefatory Note.

1 Compare pt. 3 of arts. 2 and 3 .

${ }^{45}$ Compare pt. 4 of arts. 2 and 3.

${ }^{16}$ Pt. 5 of art. 2.

${ }^{47} \mathrm{Pt} .5$ of art. 3 .

${ }^{48} \S \mathrm{I} .30 \mathrm{I}(\mathrm{I} 5)$.

40 \$ई r.30r(8), 3.106(3), 2.104(2)(a).
} 
coverage of the legislation for control of consumer credit. Stated otherwise, what is a consumer credit transaction? The UCCC answers this question by defining a consumer credit sale and a consumer loan in terms of $(a)$ who the debtor is, $(b)$ for what purpose he seeks to have credit extended, (c) the amount of credit desired, and $(d)$ the collateral or security offered for the extension of credit. ${ }^{50}$ Basically the UCCC excludes all business transactions and all transactions over $\$ 25,000$ in amount from legislative control or restrictions. The UCCC and the CCPA follow the same pattern of coverage. The disclosure requirements of the federal act are limited to those credit transactions in which the party to whom credit is extended is a natural person and in which the money, property, or services which are the subject of the credit transaction are primarily for personal, family, household, or agricultural purposes. Part 6 of the UCCC article on sales and part 6 of the UCCC article on loans, however, set maximum ceilings for charges to individuals on credit of $\$ 25,000$ or less even though the purpose of the credit is not for a personal, family, household, or agricultural purpose.

The credit sales article applies not only to a sale of goods but also to a sale of services or of an interest in land. Services include (a) work, labor, and other personal services, $(b)$ privileges with respect to transportation, hotel and restaurant accommodations, education, entertainment, recreation, physical culture, hospital accommodations, funerals, cemetery accommodations, and the like, and $(c)$ insurance provided by a person other than the insurer. ${ }^{51}$ Under the time-price doctrine it is highly debatable whether a valid time sale of a service can be consummated. Sales of an interest in land or loans secured by an interest in land in which the finance charge does not exceed ten per cent are subject only to the disclosure requirements of the UCCC and are not otherwise considered to be consumer credit transactions. $^{.2}$ The effect of this definitional treatment is to exclude the ordinary purchase-money real estate transaction at conventional rates of interest from the regulatory provisions of the act. ${ }^{53}$ All other sales of an interest in land or loans secured by an interest in land are and will be regulated as consumer credit transactions. Sales of goods and sales of an interest in land include any agreement of sale disguised in the form of a lease. ${ }^{54}$

With respect to true personal property leases, the UCCC does not undertake to regulate or control the lease charges, and in fact the only regulatory provisions of leases of personal property are those requiring disclosure of the terms of the lease agreement ${ }^{55}$ and limiting the liability of the consumer lessee upon expiration of the lease to an amount not to exceed twice the average payment allocable to a

\footnotetext{
${ }^{50} \$ \$ 2.104,3.104$.

$61 \S 2.105$.

E2 $\$ \$ 2.104(2)(b), 3 \cdot 104(2)(b)$.

${ }^{03} \$ 3.104$, Comment.

$\$ 2.105(4),(6)$.

Bt $\$ 2.3 I I$.
} 
monthly period under the lease. ${ }^{56}$ In effect this eliminates the use in the consumer field of the so-called "no-loss" lease.

\section{Finance Charges; Rate Ceilings}

With the exception of a true consumer lease transaction, the UCCC in articles 2 (for sales credit) and 3 (for loans) establishes maximum charges for the extension of credit, ${ }^{58}$ for delinquency charges, ${ }^{50}$ for deferral fees, ${ }^{60}$ and for refinancing ${ }^{01}$ and requires prepayment rebates. ${ }^{62}$ The UCCC does not undertake to fix rates for either consumer credit sales or consumer loans. Identical ceilings or maximum charges are set for both consumer sales and consumer loans. ${ }^{63}$ Maximum charges are thirty-six per cent per annum for the first three hundred dollars of credit, twenty-one per cent on the next seven hundred dollars of credit, and fifteen per cent on the amount of credit in excess of one thousand dollars or eighteen per cent per annum on the entire amount financed. The effect of this rate structure is to provide a rate curve starting at thirty-six per cent per annum for the smallest amounts of credit and decreasing in rate as the amount of credit increases graduating down to eighteen per cent at about twenty-eight hundred dollars of credit, depending, of course, upon maturity. These are the maximum allowable charges or the conscionability level of charges established by the UCCC and are not the rates which it is anticipated will be charged by creditors under the UCCC.

Both the sales article and the loan article define the finance charge ("credit service charge" for sales ${ }^{64}$ and "loan finance charge" for loans ${ }^{65}$ ) as

the sum of $[(\mathrm{x}) /(\mathrm{a})]$ all charges payable directly or indirectly by the [buyer/ debtor] and imposed directly or indirectly by the [seller/lender] as an incident to the extension of credit, including any of the following types of charges which are applicable: [time price differential, service, carrying or other charge/interest or any amount payable under a point, discount, or other system of charges], however denominated, premium or other charge or any guarantee or insurance protecting the [seller/lender] against the [buyer's/debtor's] default or other credit loss; and $[(2) /(b)]$ charges incurred for investigating the collateral or credit-worthiness of the [buyer/debtor] or for commissions or brokerage for obtaining the credit, irrespective of the person to whom the charges are paid or payable, unless the [seller/lender] had no notice of the charges when the [credit was granted/loan

$\$ 2.406$.

"77 A "no-loss lease" is one in which the parties agree that at expiration of the lease term the lessor shall sell the leased property and the lessee shall pay as additional rental any difference between the sale price and an agreed figure.

E8 $\$ \S 2.201,2.207,3.201,3.508$.

${ }^{89} \$ 52.203,3.203$.

$00 \$ \$ 2.204,3.204$.

${ }^{01} \$ \$ 2.205,3.205$.

$82 \$ \$ 2.210,3.210$.

${ }^{83} \S 2.20 \mathrm{I}$, Comment. See Johnson, supra note $4 \mathrm{I}$, at 677 .

Bs $\$ 2.109$.

of $\$ 3 . \operatorname{Iog}(\mathrm{I})$. 
was made]. The term does not include charges as a result of default, additional charges, delinquency charges, or deferral charges.

In addition to the finance charge, the creditor is authorized to charge and collect fees from the consumer for filing, perfecting, and releasing security interests, charges for insurance on the collateral involved in the transaction or for life, health, and accident coverages, and charges for such other items, as may be authorized by the consumer credit administrator, which are of value to the consumer and the cost of which is reasonable. ${ }^{68}$ The limitations and conditions under which a separate charge for insurance may be made are identical with similar provisions in the CCPA. ${ }^{67}$ In the case of collateral insurance, the consumer must be told that he has the right to purchase any required collateral insurance from an agent of his own selection and must be told in advance the cost of collateral insurance if purchased from or through the creditor. In the case of credit insurance, the consumer must be told that the coverage is not required as a condition of the extension of credit, must be given the price of the coverages offered, and must elect in writing to purchase the credit insurance.

\section{Other Provisions}

Article 4 of the UCCC contains the detailed regulations for permitted insurance coverages and the limitations and restrictions upon insurance incidental to an extension of consumer credit. Basically the UCCC incorporates the provisions of the National Association of Insurance Commissioners Model Bill ${ }^{88}$ on credit insurance and leaves to the state's insurance department or commissioner the regulation and determination of insurance rates, policies, and insurance forms. The amount and term of credit insurance are limited to the amount and the period of maturity of the indebtedness. ${ }^{69}$ No property insurance may be written unless the amount financed in the credit transaction is $\$ 300$ or more and unless the value of the property insured is also $\$ 300$ or more. ${ }^{70}$

The sales article and the loan article give the consumer the right to refinance any balloon payment in a transaction other than one primarily for an agricultural purpose on terms no less favorable to the debtor than the terms of the original transaction. ${ }^{71}$ Both articles prohibit the taking of wage assignments, ${ }^{72}$ eliminate the use of confession of judgment obligations, ${ }^{73}$ limit charges on default to those ex-

\footnotetext{
$00 \S \S 2.202,3.202$.

${ }^{07}$ Compare $\$ \$ 2.202(2), 3.202(2)$ with CCPA $\$ 106(\mathrm{~b}),(\mathrm{c})$.

${ }^{08}$ Model Bill to Provide for the Regulation of Credit Life Insurance and Credit Accident and Health Insurance (as revised December ig60), in I National Association of Insurance ComMissioners, I96r Proceedings 300; reprinted in B. CuRran, supra note 8, at 330-37.

${ }^{00} \$ \$ 4.201,4.202$.

$70 \$ 4.301$.

$71 \S \S 2.405,3.402$.

$72 \S \S 2.410,3.403$.
} 
pressly permitted by other provisions of the UCCC, ${ }^{74}$ and provide for alternative sections either prohibiting or limiting the amount of attorney fees with respect to a consumer transaction. ${ }^{75}$ In addition, the loan article prevents or prohibits the use of multiple agreements or the splitting of a single loan to obtain a higher rate of loan finance charge or to avoid disclosure, ${ }^{76}$ and, with regard to loans made at a rate of more than eighteen per cent, prohibits security interests in land where the principal of the loan is \$rooo or less, ${ }^{77}$ prohibits attorney fees, ${ }^{78}$ requires loans of $\$$ rooo or less to be payable in substantially equal installments, ${ }^{70}$ and restricts the maturities of loans of $\$ 300$ or less to not more than twenty-five months and loans of between $\$ 300$ and $\$ 1000$ to a maturity of not more than thirty-seven months. ${ }^{80}$

The sales article prohibits the use of multiple agreements with intent to obtain a higher credit service charge than would otherwise be permitted or to avoid disclosure, ${ }^{81}$ prohibits a seller or lessor from taking negotiable instruments as evidence of the buyer's or lessee's obligation, ${ }^{82}$ and, by alternative sections, would either make the assignee of a consumer credit sale or consumer lease subject to the buyer's or lessee's defenses against the original seller ${ }^{83}$ or require the assignee to give a threemonth notice period within which the buyer or lessee may assert any complaint, claim, or defense he may have against the seller or the lessor. ${ }^{84}$ The cut-off of buyers' defenses by an assignee would be available only to the assignee who acquired the contract in good faith, and if the assignee was not related to the seller or lessor. Other provisions in the sales article limit or restrict the security which the seller or lessor may take in other property of the consumer, ${ }^{85}$ control the provisions for cross-collateralization of multiple transactions, ${ }^{80}$ and fix the rules for application of payments to debts secured by cross-collateral..$^{87}$ The sales article also prohibits the use of the referral sales technique in merchandising. ${ }^{88}$ If a buyer or lessee is induced to enter into a consumer credit sale or consumer lease under a referral sales plan, then the agreement is unenforceable, and the buyer or lessee may rescind the agreement and retain the goods delivered without any obligation to pay

\footnotetext{
${ }^{73} \S 52.415,3.407$.

$74 \$ 2.414,3.405$.

$\pi 5 \$ 2.413,3.404$, Alternatives $A$ and $B$.

${ }^{76} \$ 3.509$.

$77 \$ 3.5$.0.

${ }^{78} \$ 3.511$.

$70 \$ 3.512$.

${ }^{80} \mathrm{Id}$.

$81 \S 2.402$.

$82 \$ 2.403$.

$83 \S 2.404$, Alternative A.

$84 \$ 2.404$, Alternative B.

${ }^{85} \$ 2.407$.

${ }^{80} \$ 2.408$.

${ }^{87} \S 2.409$.

${ }^{88} \$ 2.4 \mathrm{II}$. A "referral sale" is one in which the seller agrees to give the buyer a rebate or credit of a fixed amount for each new customer referred to the seller by the buyer.
} 
for them. Both the sales article and the loan article protect the buyer, lessee, or borrower who pays the original creditor until and unless notice of an assignment of the consumer credit transaction has been given. ${ }^{89}$

Article 5 of the UCCC, on remedies and penalties, as well as part 4 of articles 2 and 3, contains other limitations or restrictions on creditors' remedies and rights, but these and many of the matters referred to above will be analyzed and discussed in another article in this symposium..$^{00}$

The enforcement of the provisions of the UCCC is entrusted both to private remedies and to an administrator. These provisions also will be discussed and analyzed in another article. ${ }^{91}$

\section{E. "Cooling-Off" Periods}

The sales article of the UCCC provides special legislative controls for home solicitation sales. A home solicitation sale is defined as a consumer credit sale of goods, other than farm equipment, or services in which the seller engages in a personal solicitation of the sale at a residence of the buyer and the buyer's agreement is there given to the seller. ${ }^{92}$ In such consumer credit transactions the buyer is given a right of cancellation until midnight of the third business day after the day on which the buyer signs an agreement or offer to purchase. ${ }^{93}$ The buyer must be informed of his right to cancellation by a special notice, ${ }^{94}$ and in the event of cancellation a seller may retain as a cancellation fee five per cent of the cash price but not exceeding the amount of the cash down payment. ${ }^{95}$

Following the adoption of the CCPA by Congress, which contains a special right of rescission with respect to credit transactions where the security is a dwelling of the consumer ${ }^{96}$ the UCCC was revised to include that special provision. ${ }^{97}$ The threeday period of rescission provided for in the case of liens on dwellings applies to all security interests in residential real estate arising from either a sale or a loan, and the only exception is that of a first lien to finance the acquisition of the dwelling. ${ }^{98}$

\section{F. In Conclusion}

In capsule form these are the principal provisions of the UCCC, which is designed and intended to supplant the existing hodgepodge of consumer credit regulatory

\footnotetext{
${ }^{80} \$ \S 2.4 \mathrm{~T} 2,3.406$.

${ }^{\circ 0}$ Hogan, Integrating the UCCC and the UCC-Limitations on Creditors' Agreements and Practices, in this symposium, p. 686.

${ }^{01}$ Curran, Administration and Enforcement Under the Uniform Consumer Credit Code, this symposium, p. 737.

${ }^{02} \S 2.501$.

${ }^{03} \$ 2.502$.

of $\$ 2.503$.

${ }^{\circ 5} \$ 2.504$.

${ }^{\circ 0}$ CCPA $\$ 125$.

${ }^{07} \$ 5.204$.

${ }^{63} \$ 5.204(5)$.
} 
statutes. In my judgment, the UCCC presents an opportunity for substantial improvement in the state of the law governing consumer credit transactions. It provides a unified, harmonized, and integrated approach to legislative regulation of the consumer credit field and for the first time should enable lawyers representing either consumers or creditors quickly and effectively to advise their clients on consumer credit problems. It will substitute one coherent law for the host of separate statutes which presently exist in the consumer credit field. 